\title{
PENGARUH INSTITUTIONAL OWNERSHIP DAN FIRM SIZE TERHADAP FINANCIAL PERFORMANCE DENGAN EARNING MANAGEMENT SEBAGAI VARIABEL INTERVENING PADA PERUSAHAAN RITEL
}

\author{
Denanda Natalia Lestari Lusi ${ }^{1}$, Sukrisno Agoes $^{2}$ \\ ${ }^{1}$ Magister Akuntansi, Universitas Tarumanagara Jakarta \\ Email: denandalusi@gmail.com \\ ${ }^{2}$ Dosen Fakultas Ekonomi, Universitas Tarumanagara Jakarta
}

Masuk : 16-07-2019, revisi: 01-10-2019, diterima untuk diterbitkan : 30-10-2019

\begin{abstract}
ABSTRAK
Penelitian ini bertujuan untuk mengetahui pengaruh langsung institutional ownership dan firm size terhadap financial performance dan pengaruh tidak langsung melalui earning management pada perusahaan ritel di BEI. Jenis penelitian ini adalah kuantitatif, dimana data diperoleh dari laporan keuangan tahun 2015-2017. Teknik pengambilan sampel adalah purposive sampling, sehingga perusahaan yang dapat dijadikan sampel sebanyak 21 perusahaan dengan jumlah sampel sebanyak 63 sampel. Data yang diperoleh kemudian diolah dengan menggunakan software SmartPLS. Hasil penelitian menunjukkan bahwa ada hubungan negatif institutional ownership dengan financial performance, hubungan positif firm size dengan financial performance, hubungan positif kepemilikan institusional dan firm size dengan earning management, dan hubungan negatif earning management dengan financial performance pada perusahaan ritel. Earning management tidak dapat sebagai variabel yang mengintervensi terhadap financial performance karena hubungan langsung antara kepemilikan institusional, firm size, dan financial performance memberi pengaruh besar daripada melalui earning management.
\end{abstract}

Kata Kunci: Institutional Ownership, Firm Size, Earning Management, Financial Performace

\begin{abstract}
This study aims to determine the direct effect of institutional ownership and firm size on financial performance and the indirect effect through earnings management on retail companies on the IDX. This type of research is quantitative, where data is obtained from the 2015-2017 financial statements. The sampling technique is purposive sampling, so companies that can be sampled are 21 companies with a total sample of 63 samples. The data obtained is then processed using SmartPLS software. The results showed that there was a negative relationship between institutional ownership and financial performance, a positive relationship between firm size and financial performance, a positive relationship between institutional ownership and firm size with earnings management, and a negative relationship between earning management and financial performance in retail companies. Earning management cannot be a variable that intervenes in financial performance because the direct relationship between institutional ownership, firm size, and financial performance has a greater influence than through earning management.
\end{abstract}

Keywords: Institutional Ownership, Firm Size, Earning Management, Financial Performace

\section{PENDAHULUAN}

\section{Latar Belakang}

Perdagangan eceran kerap disebut sebagai bisnis ritel adalah kegiatan usaha menjual barang atau jasa kepada perorangan untuk keperluan diri sendiri, keluarga, atau rumah tangga (Ma'ruf, 2006, hal 7; Hasty \& Reardon, 1997, hal 10). Di tahun 2017, perkembangan bisnis ritel menjadi bahan yang menarik beberapa waktu terakhir. Pada kenyataannya walaupun tingkat pendapatan industri ritel serta pertumbuhan ekonomi yang baik justru membuat pertumbuhan penjualan industri ritel menurun. Hal ini dapat dilihat dari data yang dikeluarkan oleh Bank Indonesia dimana perkembangan bisnis ritel tahun 2017 kuartal I jauh lebih rendah dibandingkan tahun 
sebelumnya yaitu mencapai angka 3,7\%. Perkembangan dan keuntungan yang diperoleh tentu saja tidak terlepas dari kinerja keuangan perusahaan-perusahaan yang cukup baik dan berkembang (Carton \& Hofer, 2010). Salah satu sumber informasi dari pihak eksternal atau pihak diluar perusahaan dalam menilai kinerja perusahaan adalah laporan keuangan. Menurut PSAK No. 1 (2017:1), laporan keuangan merupakan suatu penyajian terstruktur dari posisi keuangan dan kinerja keuangan suatu entitas. Perusahaan mempunyai kinerja keuangan yang semakin baik dapat membuat perusahaan tersebut mampu dalam berkompetisi. Salah satu informasi yang terdapat dalam laporan keuangan adalah laba perusahaan. Oleh karena itu, laba yang dihasilkan harus berkualitas yang memiliki kemampuan prediktif, variabilitas, dan laba yang persisten (Schipper dan Vincent, 2003). Dalam menilai kinerja keuangan diperlukan alat analisis berupa rasio keuangan. Menurut Chen, et al. (2005), rasio yang digunakan yaitu Return on Equity dan Retrun on Asset.

Pada umumnya, jika penjualan atau pendapatan meningkat maka diyakini kinerja keuangan perusahaan juga akan meningkat. Namun pemikiran itu tidak selalu benar karena ada faktor faktor lain yang harus diperhatikan sebelum menilai sejauh mana kinerja perusahaan khususnya dari segi keuangan. Meningkatnya kinerja perusahaan tidak terlepas dari adanya praktek manajemen laba. Hal tersebut sering kali dilakukan oleh pihak manajemen karena adanya konflik kepentingan. Earning management merupakan suatu tindakan manajer yang memilih kebijakan akuntansi untuk mencapai beberapa tujuan yang spesifik dan kebijakan akuntansi yang dimaksud adalah penggunaan accrual dalam menyusun laporan keuangan (Scott, 2006:344). Penelitian yang dilakukan oleh Herawaty (2008), Widiatmaja (2010) dan Healy \& Wahlen (1998) menemukan bahwa manajemen laba berpengaruh terhadap kinerja keuangan dan berpengaruh positif signifikan terhadap kinerja keuangan perusahaan. Artinya, semakin tinggi manajemen laba yang dilakukan oleh manajemen maka dapat menghasilkan laba yang tinggi hasil dari campur tangan manajer sehingga perusahaan akan dinilai sangat baik.

Kepemilikan institusional merupakan salah satu faktor yang dapat meningkatkan kinerja keuangan perusahaan. Institutional ownership merupakan kepemilikan saham perusahaan yang dimiliki oleh institusi keuangan (perusahaan asuransi, bank, dana pension dan investment banking) (Siregar \& Utama, 2005 ; Tarjo, 2008). Cornett et al. (2006) menyatakan bahwa tindakan pengawas perusahaan oleh pihak investor institusional dapat mendorong manajer untuk lebih memfokuskan perhatiannya terhadap kinerja perusahaan, sehingga akan mengurangi perilaku mementingkan diri sendiri. Selain itu, dengan adanya kepemilikan institusional dapat memonitor manajemen secara efektif dan dapat meningkatkan nilai perusahaan (Shleifer \& Vishni, 1986). Berbeda dengan penelitian yang dilakukan oleh Mollah, Farooque, dan Karim (2010), menunjukan bahwa kepemilikan institusional berpengaruh negatif terhadap kinerja keuangan yang diukur dengan ROA dan ROE dimana semakin tinggi persentase kepemilikan saham oleh institusi maka semakin rendah nilai ROA dan ROE.

Ukuran perusahaan merupakan gambaran besar atau kecilnya sebuah perusahaan yang tercermin dari total aktiva perusahaan pada neraca akhir tahun (Sujoko \& Soebiantoro, 2007). Perusahaan yang memiliki total aktiva yang relatif besar mampu beroperasi dengan tingkat efisiensi yang lebih tinggi dibandingkan dengan perusahaan yang memiliki total aktiva rendah. Sehingga dengan total aktiva yang besar dapat menarik minat investor dan dijadikan sebagai patokan untuk berinvestasi karena mempunyai kinerja yang bagus yang diukur dengan Log of dari total asset (Obradovich \& Gill, 2013). Foyeke, et al. (2015) dalam penelitiannya menunjukan bahwa ukuran perusahaan berpengaruh terhadap kinerja keuangan. Investor harus mempertimbangkan ukuran perusahaan dari perusahaan tempat mereka berinvestasi serta kinerja perusahaan karena hal 
tersebut merupakan petunjuk untuk budaya tata kelola perusahaan dimana semakin besar perusahaan maka mendorong perusahaan untuk mengungkapkan informasi dalam laporan keuangan sehingga mendorong investor untuk berinvestasi. Namun, tidak sejalan dengan penelitian yang dilakukan oleh Olawale, et al. (2016), dimana ukuran perusahaan yang diukur menggunakan total asset berpengaruh negatif terhadap kinerja keuangan. Perusahaan yang memiliki asset yang besar maka semakin banyak masalah agensi yang dihadapi sehingga beban yang dikeluarkan perusahaan untuk oprasional akan semakin tinggi yang menyebabkan laba yang dihasilkan perusahaan dan ROA akan semakin kecil.

Uraian latar belakang menunjukkan bahwa pertumbuhan perusahaan ritel semakin meningkat namun masih banyak perusahaan yang melakukan manajemen laba untuk meningkatkan kinerja keuangan perusahaan, sehingga bagaimana kepemilikan institusional dan ukuran perusahaan dapat meningkatan kinerja keuangan meskipun masih ada terjadinya manajemen laba di setiap perusahan dan adanya perbedaan hasil penelitian terdahulu.

\section{Rumusan Masalah}

Berdasarkan uraian latar belakang di atas, maka yang menjadi masalah dalam penelitian ini adalah adanya kesenjangan antara temuan-temuan beberapa peneliti sehingga teori tersebut perlu dilakukan pengujian kembali dan adanya kesenjangan antara teori dengan prakteknya. Oleh karena itu, identifikasi masalah untuk penelitian ini adalah sebagai berikut:

a. Bagaimana Institutional Ownership berpengaruh terhadap Financial Performance.

b. Bagaimana Firm Size berpengaruh terhadap Financial Performance.

c. Bagaimana Institutional Ownership berpengaruh terhadap Earning Management.

d. Bagaimana Firm Size berpengaruh terhadap Earning Management.

e. Bagaimana Earning Management berpengaruh terhadap Financial Performance.

\section{METODE PENELITIAN}

Dalam bab ini akan dibahas mengenai informasi yang berhubungan dengan penelitian yaitu desain penelitian, pemilihan objek penelitian dan teknik penarikan sampel, operasional variabel dan instrument, dan program analisa data terdiri dari teknik pengolahan data dan teknik pengujian hipotesis untuk membahas dan menjawab permasalahan dalam penelitian kali ini mengenai pengaruh institutional ownership dan firm size terhadap financial performance dengan earning management sebagai variabel intervening pada perusahaan ritel.

\section{Populasi dan Teknik Penarikan Sampel}

Populasi dalam penelitian ini adalah seluruh perusahaan ritel yang terdaftar di Bursa Efek Indonesia (BEI) periode tahun 2015-2017. Teknik penelitian sampel dalam penelitian ini adalah purposive sampling. Berdasarkan pertimbangan kriteria-kriteria tertentu diperoleh jumlah perusahaan yang digunakan dalam penelitian adalah sebanyak 21 perusahaan, maka sampel yang digunakan dalam penelitian ini sejumlah 63 sampel.

\section{Operasional Variabel dan Instrumen}

Institutional Ownership (IO)

Institutional Ownership merupakan kepemilikan saham perusahaan yang dimiliki oleh institusi keuangan (perusahaan asuransi, bank, dana pension dan investment banking) (Siregar dan Utama, 2005 )

$$
\text { INST }=\frac{\text { Jumlah saham yang dimiliki oleh investor institusional }}{\text { Total saham perusahaan yang beredar secara keseluruhan }}
$$


Firm Size (FS)

Firm Size merupakan gambaran besar atau kecilnya sebuah perusahaan yang tercermin dari total aktiva dan total pernjualan perusahaan pada laporan keuangan akhir tahun (Babaloa, 2013).

\section{SIZE_TA $=$ Log of Total Assets}

\section{Earning Management (EM)}

Menejemen laba merupakan suatu tindakan yang dilakukan manajer dalam memilih kebijakan akuntansi dengan penggunaan accrual dalam menyusun laporan keuangan untuk mencapai beberapa tujuan yang spesifik (Scott, 2006:344).

Dalam mengukur discretionary accrual, menggunakan Modified Jones Model (Dechow et al., 1995)

1. Menghitung total accrual (TAC), yaitu laba bersih tahun $t$ dikurangi arus kas operasi tahun t dengan rumus sebagai berikut:

$$
\text { TAC }=\text { NIit }- \text { CFOit }
$$

Selanjutnya, menghitung total accrual (TA) diestimasi dengan Ordinary Least Square (OLS) sebagai berikut:

$$
\frac{T A_{i t}}{A_{i t-1}}=\beta_{1}\left(\frac{1}{A_{i t-1}}\right)+\beta_{2}\left(\frac{\Delta R e v_{i t}}{A_{i t-1}}\right)+\beta_{3}\left(\frac{P P E_{i t}}{A_{i t-a}}\right)+\varepsilon
$$

2. Dengan koefisien regresi seperti pada rumus di atas, Menghitung nilai nondiscretionary accrual (NDA):

$$
N D A_{i t}=\beta_{1}\left(\frac{1}{A_{i t-1}}\right)+\beta_{2}\left(\frac{\Delta R e v_{i t}}{A_{i t-1}}-\frac{\Delta R e c_{i t}}{A_{i t-1}}\right)+\beta_{3}\left(\frac{P P E_{i t}}{A_{i t-1}}\right)
$$

3. Menghitung nilai discretionary accruals (DA), sebagai ukuran manajemen laba ditentukan dengan formula sebagai berikut:

$$
D A_{i t}=\frac{T A_{i t}}{A_{i t-1}}-N D A_{i t}
$$

Keterangan :

$D A_{\text {it }} \quad=$ Discretionary Accruals perusahaan i dalam periode tahun $\mathrm{t}$

$N D A_{i t} \quad=$ Nondiscretionary Accruals perusahaan i dalam periode tahun $\mathrm{t}$

$T A_{i t} \quad=$ Total acrual perusahaan $\mathrm{i}$ dalam periode tahun $\mathrm{t}$

$N I_{\text {it }} \quad=$ Laba bersih perusahaan i dalam periode tahun $\mathrm{t}$

$\mathrm{CFO}_{\mathrm{it}} \quad=$ Arus kas dari aktivitas operasi perusahaan i dalam periode tahun $\mathrm{t}$

$A_{i t-1}=$ Total aset perusahaan i dalam periode tahun $\mathrm{t}-1$

$\Delta \operatorname{Rev}_{i t}=$ Pendapatan perusahaan $\mathrm{i}$ pada tahun $\mathrm{t}$ dikurangi dengan pendapatan perusahaan i pada tahun $\mathrm{t}-1$

$P P E_{i t} \quad=$ Property, pabrik, dan peralatan perusahaan i dalam periode tahun $\mathrm{t}$

$\Delta \operatorname{Rec}_{\text {it }} \quad=$ Piutang usaha perusahaan I pada tahun $\mathrm{t}$ dikurangi pendapatan perusahaan I pada tahun $\mathrm{t}-1$.

$\varepsilon \quad=$ error 
Financial Performance (FP)

Carton (2010) mendefinisikan kinerja keuangan sebagai ukuran dari perubahan kondisi keuangan suatu organisasi, atau hasil dari keputusan manajemen dan pelaksanaan keputusannya oleh anggota organisasi.

1. Return on Equity (ROE)

$$
R O E=\frac{\text { Net Income }}{\text { Total Equity }}
$$

2. Return on Asset (ROA)

$$
R O A=\frac{\text { Net Income }}{\text { Total Asset }}
$$

\section{Teknik Pengumpulan Data}

Penelitian ini menggunakan data sekunder yang meliputi laporan keuangan publikasi tahunan (annual report) tahun 2015-2017. Teknik pengumpulan data yang dilakukan dengan studi pustaka dan dokumentasi. Studi pustaka digunakan sebagai landasan bagi perumusan hipotesis melalui jurnal, buku, literature, serta sumber informasi lainnya terkait variable yang diuju.dan pembahasan dengan mengumpulkan data-data yang berkaitan dengan penelitian ini melalui beberapa artikel yang relevan dari media-media, internet, dan literatur-literatur yang berkaitan dengan penelitian. Dokumentasi data dilakukan dengan mengambil data yang telah tersedia dan dipublikasikan oleh Bursa Efek Indonesia (www.idx.co.id).

\section{Teknik Analisa Data}

\section{Mengkonstruksi diagram path}

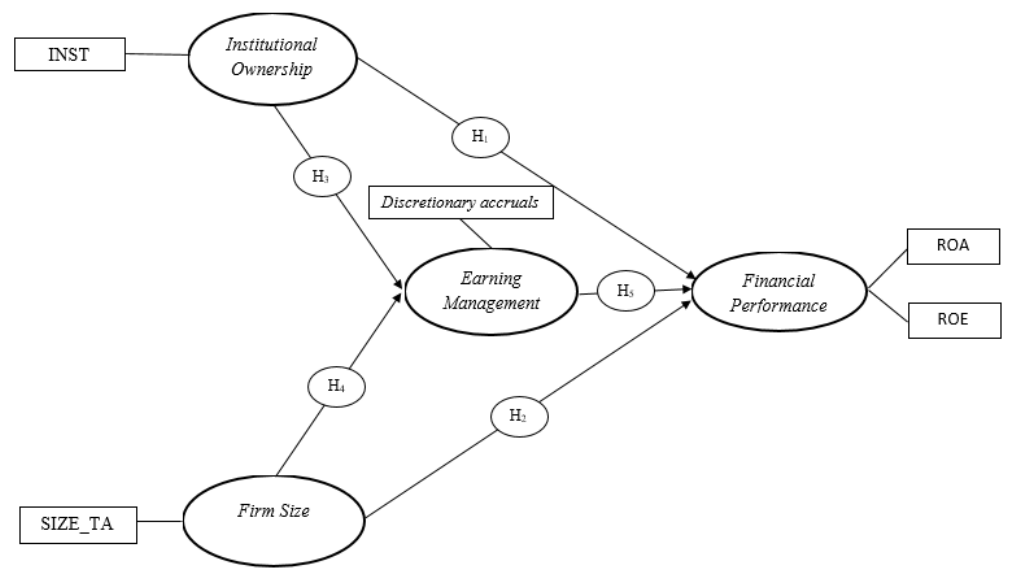

Gambar 1. Diagram Path Partial Least Square

\section{Evaluasi Goodness-of-fit Outer Model}

Penelitian ini dapat diukur validitas dan reliabilitasnya melalui evaluasi Goodness-of-fit outer model. Evaluasi untuk outer model atau model pengukuran dapat dilakukan melalui Convergent validity, Discriminant Validity, dan Composite Reliability.

\section{Evaluasi Goodness-of-fit Inner Model}

Inner model atau model struktural dilakukan dengan melihat presentase varian yang dijelaskan yaitu dengan melihat R2 untuk konstruk laten dependen, Stone-Geisser Qsquare Itest (Ghozali, 2011) dan juga melihat besarnya jalur koefisien jalur strukturalnya. 


\section{HASIL DAN PEMBAHASAN}

\section{Analisis Statistik Deskriptif}

hasil statistik deskriptif yang terdiri dari nilai minimum, nilai maksimum, rata-rata, dan standar deviasi dari variabel independen penelitian yaitu institutional ownership dan firm size terhadap variabel dependen penelitian yaitu financial performance melalui variabel intervening penelitian yaitu earning management :

Tabel 1. Hasil Statistik Deskriptif

Sumber : Hasil pengolahan Microsoft Excel 2010

\begin{tabular}{|l|r|r|r|r|r|}
\hline \multicolumn{1}{|c|}{ Variabel } & N & \multicolumn{1}{c|}{ Mean } & \multicolumn{1}{c|}{ Minimum } & \multicolumn{1}{c|}{ Maximum } & \multicolumn{1}{c|}{ Std. Deviasi } \\
\hline Institutional Ownership & 63 & 0.67612 & 0.17478 & 1.00000 & 0.19196 \\
\hline Firm Size & 63 & 12.27117 & 10.78399 & 13.34048 & 0.67965 \\
\hline Earning Management & 63 & -0.09432 & -0.90907 & 0.20637 & 0.17063 \\
\hline Financial Performance (ROE) & 63 & -281.52928 & -18093.72013 & 98.85043 & 2280.58049 \\
\hline Financial Performance (ROA) & 63 & -1659.44457 & -105683.25557 & 315.09927 & 13317.30278 \\
\hline
\end{tabular}

\section{Analisis Partial Least Square}

\section{a. Outer Model}

\section{Convergent Validity}

Berikut adalah hasil convergent validity untuk variabel institutional ownership, firm size, earning management dan financial performance pada tabel 4.3.

Tabel 2. Nilai Outer Loading

Sumber : Hasil pengolahan Software SmartPLS

\begin{tabular}{|c|l|c|}
\hline Variabel & \multicolumn{1}{|c|}{ Indikator } & Outer Loading \\
\hline Institutional Ownership & Institutional Ownership & 1.000000 \\
\hline Firm Size & Log of Total Assets & 1.000000 \\
\hline \multirow{2}{*}{ Earning Management } & Discretionary Accruals & 1.000000 \\
\hline \multirow{2}{*}{ Financial Performance } & ROE & 0.999984 \\
\cline { 2 - 3 } & ROA & 0.999984 \\
\hline
\end{tabular}

Pada tabel 2., terlihat bahwa semua outer loading $>0.50$ sehingga dapat diartikan masing-masing indikator dalam variabel terbukti valid signifikan yang berperan untuk mengukur masing-masing variabel. Pada variabel institutional ownership, outer loading pada institutional ownership sebesar 1.000000. Pada variabel firm size, outer loading sebesar 1.000000. Pada variabel earning management, outer loading pada discretionary accruals sebesar 1.000000. Pada variabel financial performance, outer loading pada return on asset dan return on equity sebesar 0.999984 .

\section{Discriminant Validity}

Berikut merupakan tabel hasil average variance extracted (AVE).

Tabel 3. Average Variance Extracted (AVE)

\begin{tabular}{|c|c|c|c|c|c|c|}
\hline & AVE & Akar AVE & EM & FP & FS & IO \\
\hline EM & 1.000000 & 1.000000 & 1.000000 & & & \\
\hline FP & 1.000000 & 1.000000 & -0.109176 & 1.000000 & & \\
\hline FS & 1.000000 & 1.000000 & 0.213479 & 0.080300 & 1.000000 & \\
\hline OI & 1.000000 & 1.000000 & 0.129364 & -0.154215 & -0.396684 & 1.000000 \\
\hline
\end{tabular}


Berdasarkan hasil tabel 3, dapat dilihat bahwa nilai AVE untuk variabel institutional ownership, firm size, earning management dan financial performance sebesar 1.000000. Oleh karena itu, berdasarkan hasil tersebut dapat dikatakan model tersebut telah memiliki descriminant validity yang baik karena telah memenuhi kriteria yang ditentukan yaitu diatas 0.50 .

Tabel 4. Nilai Cross Loading

Sumber : Hasil pengolahan Software SmartPLS

\begin{tabular}{|l|c|c|c|c|}
\hline & $\begin{array}{c}\text { Earning } \\
\text { Management }\end{array}$ & $\begin{array}{c}\text { Financial } \\
\text { Performance }\end{array}$ & Firm Size & $\begin{array}{c}\text { Institutional } \\
\text { Ownership }\end{array}$ \\
\hline DAit & $\mathbf{1 . 0 0 0 0 0 0}$ & -0.109176 & 0.213479 & 0.129364 \\
\hline ROE & -0.109526 & $\mathbf{0 . 9 9 9 9 8 4}$ & 0.080171 & -0.153975 \\
\hline ROA & -0.108823 & $\mathbf{0 . 9 9 9 9 8 4}$ & 0.080426 & -0.154450 \\
\hline Firm Size & 0.213479 & 0.080300 & $\mathbf{1 . 0 0 0 0 0 0}$ & -0.396684 \\
\hline Institutional Ownership & 0.129364 & -0.154215 & -0.396684 & $\mathbf{1 . 0 0 0 0 0 0}$ \\
\hline
\end{tabular}

Berdasarkan tabel 4., dapat disimpulkan bahwa masing- masing indikator yang ada di suatu variabel laten memiliki perbedaan dengan indikator di variabel lain yang ditunjukkan dengan skor loadingnya yang lebih tinggi di konstruknya sendiri. Dengan demikian, model dalam penelitian ini telah mempunyai validitas diskriminan yang baik

\section{Composite Reliability}

Berikut adalah tabel hasil output composite reliability.

Tabel 5. Composite Reliability

Sumber : Hasil pengolahan Software SmartPLS

\begin{tabular}{|c|c|}
\hline & Composite Reliability \\
\hline Earning Management & 1.000000 \\
\hline Financial Performance & 0.999984 \\
\hline Firm Size & 1.000000 \\
\hline Institutional Ownership & 1.000000 \\
\hline
\end{tabular}

Berdasarkan tabel 5., menunjukan bahwa model dalam penelitian ini telah reliabel. Hal tersebut dapat dilihat dari hasil output yang menujukkan nilai variabel institutional ownership, firm size, earning management sebesar 1.000000, dan financial performance sebesar 0.999984.

\section{b. Outer Model}

\section{R-Square}

Berdasarkan pengolahan data, dihasilkan nilai koefisien determinasi ( $R$-Square) sebagai berikut:

Tabel 6. Nilai $R$-Square Model

Sumber : Hasil pengolahan Software SmartPLS

\begin{tabular}{|c|c|}
\hline & R-Square \\
\hline Earning Management & 0.099946 \\
\hline Financial Performance & 0.034293 \\
\hline Institutional Ownership & \\
\hline Firm Size & \\
\hline
\end{tabular}

Penilaian goodness of fit pada model dapat diketahui dari nilai $\mathrm{Q}^{2} . Q$-square dapat mengukur seberapa baik nilai observasi yang dihasilkan oleh model dan juga estimasi parameternya. 
Semakin tinggi $\mathrm{R}^{2}$, maka model dapat dikatakan semakin fit dengan data. Dari Tabel 6 diatas, dapat diketahui nilai $\mathrm{Q}^{2}$ sebagai berikut :

$$
\text { Nilai } \begin{aligned}
Q^{2} & =1-(1-0.099946) \times(1-0.034293) \\
& =0.13138
\end{aligned}
$$

Dari hasil perhitungan nilai $Q^{2}$ sebesar 0.13138 , artinya besarnya keragaman dari data penelitian yang dapat dijelaska oleh model struktural adalah sebesar $13.13 \%$, sedangkan sebesar $86.87 \%$ sisanya dijelaskan oleh variabel lain diluar model.

Tabel 7. Direct and Indirect Effect

Sumber : Hasil Olahan

\begin{tabular}{|l|c|c|}
\hline \multicolumn{1}{|c|}{ Pengaruh } & Direct Effect & Indirect Effect \\
\hline Intitutional Ownership $\rightarrow$ Financial performance & -0.118334 & - \\
\hline Firm Size $\rightarrow$ Financial Perfomance & 0.055947 & - \\
\hline Institutional Ownership $\rightarrow$ Earning Management & - & $0.254020 \times-0.105811=$ \\
$\rightarrow$ financial performance & - & 0.02687 \\
\hline Firm Size $\rightarrow$ Earning Management $\rightarrow$ Financial & - & $0.314245 \times-0.105811=-$ \\
performance & - & 0.03325 \\
\hline Institutional Ownership $\rightarrow$ Earning Management & 0.254020 & - \\
\hline Firm Size $\rightarrow$ Earning Management & 0.314245 & - \\
\hline Earning Management $\rightarrow$ Financial performance & -0.105811 & - \\
\hline
\end{tabular}

Berdasarkan tabel 7., merupakan hasil pengujian pengaruh langsung dan pengaruh tidak langsung dari institutional ownership terhadap financial performance melalui earning management yaitu sebesar -0.02687, dimana lebih besar bila dibandingkan dengan hubungan langsung diantara masing-masing variabel institutional ownership dan financial performance. Sehingga dapat disimpulkan bahwa earning management sebagai variabel intervening, secara bersama-sama mampu memediasi pengaruh institutional ownership terhadap financial performance.

Pengaruh langsung dan pengaruh tidak langsung dari firm size terhadap financial performance melalui earning management yaitu sebesar -0.03325, dimana lebih kecil bila dibandingkan dengan hubungan langsung diantara masing-masing variabel firm size dan financial performance. Sehingga dapat disimpulkan bahwa earning management sebagai variabel intervening, secara bersama-sama tidak mampu memediasi pengaruh firm size terhadap financial performance.

\section{Uji Hipotesis}

Uji hipotesis analisa Partial Least Square juga menghasilkan koefisien path pada inner model sebagai berikut :

Tabel 8. Hasil Inner Weight

Sumber : Hasil pengolahan Software SmartPLS

\begin{tabular}{|l|l|c|c|c|c|}
\hline \multirow{5}{*}{ Nilai } & $\begin{array}{c}\text { Original } \\
\text { Sample (O) }\end{array}$ & $\begin{array}{c}\text { Sample } \\
\text { Mean (M) }\end{array}$ & $\begin{array}{c}\text { Standard } \\
\text { Deviation } \\
\text { (STDEV) }\end{array}$ & $\begin{array}{c}\text { T Statistics } \\
(\text { (O/STERR|) }\end{array}$ \\
\cline { 2 - 6 } & IO $\rightarrow$ FP & -0.118334 & -0.089139 & 0097573 & 1.212771 \\
\cline { 2 - 6 } & FS $\rightarrow$ FP & 0.055947 & 0.093608 & 0.085360 & 0.655422 \\
\cline { 2 - 6 } IO $\rightarrow$ EM & 0.254020 & 0.247483 & 0.097129 & 2.615280 \\
\hline FS $\rightarrow$ EM & 0.314245 & 0.307816 & 0.103640 & 3.032083 \\
\hline EM $\rightarrow$ FP & -0.105811 & -0.102732 & 0.052567 & 2.012907 \\
\hline
\end{tabular}


koefisien path pengaruh dari variabel institutional ownership terhadap financial performance sebesar -0.118334 dengan t hitung sebesar 1.212771 yang lebih kecil dari nilai t tabel 1.96, angka tersebut menunjukkan bahwa terdapat pengaruh negatif tidak signifikan antara institutional ownership terhadap financial performance pada sektor ritel. Dari hasil tersebut maka hipotesis pertama dari penelitian ditolak kebenarannya.

Nilai koefisien path pengaruh dari variabel firm size terhadap financial performance sebesar 0.055947 dengan t hitung sebesar 0.655422 yang lebih kecil dari nilai t tabel 1.96, angka tersebut menunjukkan bahwa terdapat pengaruh positif tidak signifikan antara firm size terhadap financial performance pada sektor ritel. Dari hasil tersebut maka hipotesis kedua dari penelitian dapat ditolak kebenarannya.

Nilai koefisien path pengaruh dari variabel institutional ownership terhadap earning management sebesar 0.254020 dengan t hitung sebesar 2.615280 yang lebih besar dari nilai $t$ tabel 1.96, angka tersebut menunjukkan bahwa terdapat pengaruh positif yang signifikan antara institutional ownership terhadap earning management pada sektor ritel. Dari hasil tersebut maka hipotesis ketiga dari penelitian dapat diterima kebenarannya.

Nilai koefisien path pengaruh dari variabel firm size terhadap earning management sebesar 0.314245 dengan t hitung sebesar 3.032083 yang lebih besar dari nilai t tabel 1.96, angka tersebut menunjukkan bahwa terdapat pengaruh positif yang signifikan antara firm size terhadap earning management pada sektor ritel. Dari hasil tersebut maka hipotesis keempat dari penelitian dapat diterima kebenarannya.

Nilai koefisien path pengaruh dari variabel earning management terhadap financial performance sebesar -0.105811 dengan t hitung sebesar 2.012907 yang lebih kecil dari nilai t tabel 1.96, angka tersebut menunjukkan bahwa terdapat pengaruh negatif tidak signifikan antara earning management terhadap financial performance pada sektor ritel. Dari hasil tersebut maka hipotesis kelima dari penelitian dapat ditolak kebenarannya.

\section{KESIMPULAN DAN SARAN}

Dari data yang telah di peroleh dari hasil penelitian menggunakan SmartPLS, maka dapat diperoleh kesimpulan bahwa institutional ownership mempunyai pengaruh negatif tidak signifikan terhadap financial performance, firm size mempunyai pengaruh positif tidak signifikan terhadap financial performance, institutional ownership mempunyai pengaruh positif signifikan terhadap earning management, firm size mempunyai pengaruh positif signifikan terhadap earning managemen, earning manageement mempunyai pengaruh negatif dan signifikan terhadap financial performance. Selain itu, ditemukan adanya pengaruh tidak langsung antara institutional ownership terhadap financial performance melalui earning management yang memberi pengaruh lebih besar dibandingkan dengan pengaruh secara langsung. Kemudian, adanya pengaruh tidak langsung antara firm size terhadap financial performance yang memberikan pengaruh lebih kecil dibandingkan pengaruh langsung. Dengan demikian, dapat disimpulkan bahwa variabel earning management mampu menjadi variabel intervening antara institutional ownership terhadap financial performance namun tidak mampu menjadi variabel intervening antara firm size terhadap financial performance.

Untuk penelitian selanjutnta, diharapkan dapat memperluas objek penelitian serta penembahan rasio keuangan lainnya yang dapat mempengaruh kinerja keuangan perusahaan karena berdasarkan hasil olahan data tersebut, diketahui bahwa nilai $\mathrm{Q}^{2}$ sebesar 0.13138 atau $13.13 \%$, 
menunjukkan besarnya tingkat keragaman data hanya dapat dijelaskan oleh model struktural sebesar $13.13 \%$ dan $86.87 \%$ dapat dijelaskan oleh variabel lain. Oleh karena itu, peneliti menyarankan bagi peneliti selanjutnya dapat menggunakan variabel lain yang tidak digunakan dalam penelitian ini diantaranya board size, kepemilikan manajerial, leverage serta diharapkan dapat menambah periode penelitian. Hal ini karena dengan semakin panjangnya jangka waktu penelitian dapat memberikan gambaran yang lebih relevan mengenai pengaruh variabel terhadap kinerja keuangan.

\section{REFERENSI}

Babalola, Yisau Abiodun (2013). The Effect of Firm Size on Firms Profitability in Nigeria. Journal of Economics and Sustainable Development. 4 (5)

Carton, R. B., \& Hofer, C. W. (2010). Organizational Financial Performance: Identifying and Testing Multiple Dimensions. Academy of Enterpreneurship Journal , 16 (1).

Chen, M.C., Cheng, Shu-Ju., \& Hwang, Y. (2009). An Empirical Investigation of the Relationship between Intellectual Capital and Firms' Market Value and Financial Performance. Journal of Management, 17 (1), 99-120

Cornett, M. M., Marcus, A. J., Saunders, A., \& Tehranian, H (2006). Earnings Management, Corporate Governance, and True Financial Performance.

Dechow, Patricia M., Sloan, Richard G., \& Sweeney, Amy P. (1995). Detection Earning Management. The Accounting Review. 70, 193-225

Foyeke, Obigbemi Imoleayo., Odianonsen, Iyoha Francis., \& Aanu, Ojeka Stephen (2015). Firm Size and Financial Performance: A Determinant of Corporate Governance Disclosure Practices of Nigerian Companies. Journal of Accounting and Auditing: Research \& Practice. 2015

Ma'ruf, H. (2006). Pemasaran Retail. Jakarta: PT Gramedia Pustaka Utama.

Mollah, Sabur., Farooque, Omar Al., \& Karim, Wares. (2010). Ownership Structure, Corporate Governance and Firm Governance: Evidence from an African Emerging Market. Studies in Economics and Finance. 29 (4), 301-319

Hasty, Ron., \& Reardon, James. (1997). Retail Management. New York: International Edition. McGrow-hill.

Healy, Paul M., \& Wahlen, James Michael. (1984). The Effect of Bonus Schemes on Accounting Decisions. Journal of Accounting and Economy. 7, 85-107

Herawaty, Vinola. (2008). Peran Praktek Corporate Governance Sebagai Moderating Variabel dari Pengaruh Earning Management Terhadap Nilai Perusahaan. Jurnal Akuntansi dan Keuangan, 10 (2), 97-108. ISSN 2338-8137

Ikatan Akuntansi Indonesia (IAI). (2017). Pernyataan Standar Akuntansi Keuangan (PSAK) No. 1: Penyajian Laporan Keuangan. Jakarta: IAI

Mollah, Sabur., Farooque, Omar Al., \& Karim, Wares. (2010). Ownership Structure, Corporate Governance and Firm Governance: Evidence from an African Emerging Market. Studies in Economics and Finance. 29 (4), 301-319

Obradovich, .J.D., \& Gill, A. 2012. The Impact of Corporate Governance and Financial Leverage on the Value of American Firms. International Research Journal of Finance and Economics. Issue 91, 1-14

Olawale, Luqman S., Ilo, Bamidele M., \& Lawal, Fatai K. (2017). The effect of firm size onperformance of firms in Nigeria, AESTIMATIO, The IEB International Journal of Finance. 15, 2-21

Schipper, K., \& Vincent, L. (2003). Earning Quality. Accounting Horizons, 17, 97-110

Scott, William R. (2006). Financial Accounting Theory. Edisi Keempat. USA: Prentice Hall 
Shleifer, Andrei \& Vishny, Robbert W. (1997). A Survey of Corporate Governance. The Journal of Finance. 52 (2)

Siregar, N.V.N.P \& Utama, Siddharta. (2005). Pengaruh Struktur Kepemilikan, Ukuran, Perusahaan, Dan Praktek Corporate Governance Terhadap Pengelolaan Laba (Earnings Management). Simposium Nasional Akuntansi VIII. Solo

Sujoko \& Soebiantoro, U. 2007. Pengaruh Struktur Kepemilikan Saham, Leverage, Faktor Interen dan Faktor Eksteren terhadap Nilai Perusahan. Jurnal Manajemen dan Kewirausahaan. 9 (1)

Tarjo. 2008. "Pengaruh Konsentrasi Kepemilikan Institusiona dan Leverage Terhadap Manajemen Laba, Nilai Pemegang saham serta Cost of Equity Capital”. Simposium Nasioanal Akuntansi XI. Pontianak

Widiatmaja, Bayu Fatma. (2010). Pengaruh Mekanisme Corporate Gorvenance Terhadap Manajemen Laba dan Konsekuensi Manajemen Laba Terhadap Kinerja Keuangan (Studi Pada Perusahaan Manufaktur Tahun 2006-2008). Skripsi. Fakultas Ekonomi, Universitas Diponegoro, Semarang 